Editorial

www.mdpi.com/journal/remotesensing

\title{
Remote Sensing Best Paper Award 2013
}

\section{Prasad Thenkabail}

Editor-in-Chief, Research Geographer 15, United States Geological Survey (USGS), 2255, N. Gemini Dr., Flagstaff, AZ 86001, USA; E-Mail: pthenkabail@usgs.gov

Received: 15 February 2013 / Accepted: 15 February 2013 / Published: 20 February 2013

Remote Sensing has started to institute a "Best Paper" award to recognize the most outstanding papers in the area of remote sensing techniques, design and applications published in Remote Sensing. We are pleased to announce the first "Remote Sensing Best Paper Award" for 2013. Nominations were selected by the Editor-in-Chief and selected editorial board members from among all the papers published in 2009. Reviews and research papers were evaluated separately. We are pleased to announce that the following three papers have won the Remote Sensing Best Paper Award in 2013:

Article Award:

$1^{\text {st }}$ Prize

\section{Sanna Kaasalainen, Anssi Krooks, Antero Kukko and Harri Kaartinen}

Radiometric Calibration of Terrestrial Laser Scanners with External Reference Targets Remote Sens. 2009, 1(3), 144-158; doi:10.3390/rs1030144

Available online: http://www.mdpi.com/2072-4292/1/3/144

$2^{\text {nd }}$ Prize

Steffen Fritz, Ian McCallum, Christian Schill, Christoph Perger, Roland Grillmayer, Frédéric Achard, Florian Kraxner and Michael Obersteiner

Geo-Wiki.Org: The Use of Crowdsourcing to Improve Global Land Cover

Remote Sens. 2009, 1(3), 345-354; doi:10.3390/rs1030345

Available online: http://www.mdpi.com/2072-4292/1/3/345

\section{Review Award:}

\section{Susan Kay, John D. Hedley and Samantha Lavender}

Sun Glint Correction of High and Low Spatial Resolution Images of Aquatic Scenes: a Review of Methods for Visible and Near-Infrared Wavelengths

Remote Sens. 2009, 1(4), 697-730; doi:10.3390/rs 1040697

Available online: http://www.mdpi.com/2072-4292/1/4/697 
We believe these three exceptional papers represent valuable contributions to Remote Sensing and the scientific literature. On behalf of the Prize Awarding Committee and the Editorial Board of Remote Sensing, we would like to congratulate these three teams for their excellent work. In recognition for their accomplishment, Dr. Sanna Kaasalainen and Dr. Steffen Fritz will be awarded prizes of $600 \mathrm{CHF}$ and $400 \mathrm{CHF}$, respectively, and the privilege of publishing an additional paper of their choice free of charge in open access format in Remote Sensing, after the usual peer-review procedure. Dr. Susan Kay will be awarded the same privilege of publishing a research paper free of charge in Remote Sensing, as well.

Prize Awarding Committee

Editor-in-Chief

Prof. Dr. Prasad S. Thenkabail

Research Geographer 15, United States Geological Survey (USGS), 2255, N. Gemini Dr., Flagstaff, AZ 86001, USA

E-Mail: pthenkabail@usgs.gov

Editorial Board Member

Prof. Dr. Wolfgang Wagner

Research Group Remote Sensing, Department of Geodesy and Geoinformation (GEO), Vienna University of Technology (TU Wien), Gusshausstrasse 27-29, 1040 Vienna, Austria

E-Mail:ww@ipf.tuwien.ac.at

Editorial Board Member

Prof. Dr. Giles Foody

School of Geography, University of Nottingham, Nottingham, NG7 2RD, UK

E-Mail: giles.foody@nottingham.ac.uk

\section{Editorial Board Member}

\section{Prof. Dr. Alfredo R. Huete}

Plant Functional Biology and Climate Change Cluster, School of Environment, University of Technology Sydney, 15 Broadway Road, Ultimo, NSW 2007, Australia

E-Mail: alfredo.huete@uts.edu.au

(C) 2013 by the authors; licensee MDPI, Basel, Switzerland. This article is an open access article distributed under the terms and conditions of the Creative Commons Attribution license (http://creativecommons.org/licenses/by/3.0/). 